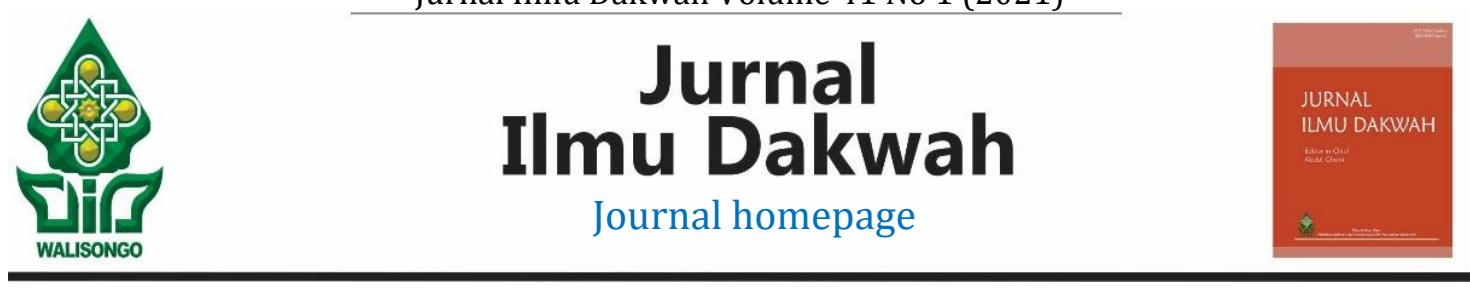

\title{
Mechanization of Islamic moderation da'wah in the Nahdlatul Ulama pesantren tradition
}

\author{
Kamilia Hamidah' ${ }^{1}$, Arif Chasannudin² \\ 1,2Institut Pesantren Mathali'ul Falah, Pati \\ 1Email: kamiliahamidah@ipmafa.ac.id \\ 2Email: arif@ipmafa.ac.id
}

\begin{abstract}
Pesantren (madrassah) is Indonesia's oldest educational institution; it is through pesantren (madrassah) that the country's national educational system was formed, and despite the rapid changes in society, pesantren has managed to keep its characteristics. The kyai, santri, mosque, and classical reference books are at least three key parts of pesantren culture (Kitab Kuning). Pesantren play a critical role in distributing Islamic moderation in the society to maintain community resilience, since the tendency of social religiosity in today's Indonesian culture has reached into religious conservatism to some extent. The objective of this research is to describe pesantren elements (Kyai, Santri, Masjid, and Kitab Kuning) are engaged in producing religious moderation character-building approaches and patterns. This research examines five renowned Nahdhatul Ulama pesantren in Central and East Java using a qualitative methodology. According to results this study that based on in-depth observations, documentation, and observation of the pesantren environment under independent investigation, as well as interviews with pesantren leaders (kyai) and other informants who are fully acquainted with the pesantren under research. The PesantrenIslamic boarding school-style integrated education system and the classical halaqah system, according to the findings of this study, became an integrated and complementary educational system, preparing social cadre with an understanding of religious moderation, which was actualized in the form of national commitment, religious tolerance, anti-violence da'wah, and accommodative behavior to local culture. The results of this study can be implemented that the four elements of pesantren can be used as a strategy in strengthening the values of islamic moderation not limited to the pesantren but extended to the scope of national life.
\end{abstract}

Keywords: Pesantren, kyai, santri, education, islamic moderation. 


\begin{abstract}
Abstrak
Pesantren adalah lembaga pendidikan tertua di Indonesia; Dari pesantren (madrasah) perkembangan sistem pendidikan nasional di Indonesia terbangun, meski terjadi perubahan masyarakat yang dinamis, pesantren tetap mampu mempertahankan ciri khasnya. Setidaknya ada tiga unsur penting dalam budaya pesantren, yaitu kyai, santri, masjid, dan kitab klasik (kitab kuning). Tren religiusitas sosial dalam masyarakat Indonesia saat ini - sampai batas tertentu - telah menunjukkan gejala ke arah konservatisme agama, oleh karena itu pesantren memainkan peran krusialnya dalam mensosialisasikan diskursus moderasi Islam di masyarakat untuk membentengi sekaligus membangun resiliensi sosial dari arus konservatisme agama yang ekstrem. Tujuan dalam penelitian ini adalah menggambarkan elemen pesantren (Kyai, Santri, Masjid, dan Kitab Kuning) yang digunakan dalam mengembangkan strategi dan pola pembentukan karakter moderasi beragama. Studi ini menggunakan pendekatan kualitatif fenomenologis dengan melihat lima pesantren ikonic Nahdhatul Ulama di Jawa Tengah dan Jawa Timur. Berdasarkan hasil observasi mendalam dengan mendokumentasikan dan mengamati lingkungan pesantren melalui inkuiri independen, serta wawancara mendalam dengan beberapa informan yang benarbenar mengenal pesantren yang menjadi objek kajian. Selanjutnya temuan penelitian ini, sistem pendidikan terpadu ala pesantren dan sistem halaqah klasik-sistem pendidikan terpadu dan komplementer pesantren- telah mampu mempersiapkan kader masyarakat yang memahami moderasi beragama, yang diaktualisasikan dalam bentuk komitmen kebangsaan, toleransi beragama, dakwah tanpa kekerasan, dan perilaku akomodatif terhadap budaya lokal. Hasil kajian ini dapat diimplementasikan bahwa empat elemen pesantren dapat dijadikan strategi dalam memperkuat nilai-nilai moderasi beragama tidak terbatas pada lingkungan pesantren tapi diperluas pada lingkup kehidupan berbangsa dan bernegara.
\end{abstract}

Kata Kunci: Pesantren, kyai, santri, pendidikan, moderasi Islam.

\title{
1. PENDAHULUAN
}

Pesantren (madrassah) is Indonesia's oldest educational institution, dating back hundreds of years. Pesantren have been a component of traditional forms of education in Indonesia for generations, and they may make a significant contribution to the country's educational growth. As an ulama (intellectual) educational institution, the pesantren's duty to people is to deepen religious knowledge (tafaqquh fiddin) and to inspire ulama cadres in their purpose and duty as the Prophets' successors (warasat al anbiya).

Pesantren, according to Nurcholis Madjid, has a one-sided connotation, both Islamic and indigenous (Indonesian). According to him, pesantren can refer to a site for students or pesantren students, while 'santri' is derived from the Sanskrit word'sastri,' which means educated people, and 'cantrik,' which indicates individuals who always follow their teacher wherever they go (Madjid, 1997)

The survival of pesantren until recently is not only to the fact that pesantren is synonymous with the meaning of Islam, but also to the fact that its very presence indicates the meaning of indigenous. Pesantren grow and evolve as indigenous people as a result of the dynamic sociological experience of the people in their surroundings. There is a hypothesis that if we are never colonized, the school system will develop along the same lines as the pesantren. As a result, today's universities may be known as Tremas University, Krapyak University, Tebuireng University, Bangkalan University, Lasem University, and 
others. We may reach this conclusion by seeing and comparing the school system in the West, where practically everyone is educated. (Shiddiq, 2005).

According to the Ministry of Religion's pesantren database, at least 25,938 pesantren with 3,962,700 students (santri) are situated over 34 provinces in Indonesia, with around 79.93 percent of students (santri) living in boarding schools (Ministry of Religious Affairs, 2019). Meanwhile, the percentage of santri distribution by gender is approximately $1,886,748$ male students (50.19 percent) and 1,872,450 female students (49.81 percent) (Ministry of Religious Affairs, 2019). This data indicates that pesantren are very accommodating in providing opportunities for women to join pesantren, indicating that pesantren is not only dominated by male student.

The most difficult task confronting this country is the developing symptoms of intolerance in our culture, even though several incidents of intolerance concerns have not yet disappeared since the beginning of reform. According to the National Committee on Human Rights report, charges of abuses of freedom of belief are on the rise, with 74 complaints in 2014 and 89 in 2015. According to the most recent data filed by the Coordinator of the National Human Rights Commission's Dessk on Freedom of Religion and Belief, Komnas HAM received ten new complaints from July to September 2016 (Kompas $04 / 10 / 2016)$. These complaints are in addition to the 34 instances that were filed after the first six months.

The data above is due to a declining sense of national solidarity, which has resulted in exclusive individuals who believe they have the authority to judge differences from the standpoint of certain groups. On the other hand, increasing religiosity is becoming more evident in the public sphere, having a significant ideological, social, and economic influence. In both urban and rural places, the direction of religious speeches or studies should have included inclusive principles that encourage tolerance, moderation, and peace.

As a matter of fact, fostering a culture of peace requires the involvement of santri, who will serve as a frontline actor in grassroot society. In this way, santri empowerment should be integrated with efforts to achieve long-term development, as santri is a member of the next generation of social change agents (Karim et al, 2019).

The pesantren, as an Islamic educational institution in Indonesia, attempts to develop Islamic personality qualities in Muslim persons via their patterns of thinking, attitudes, and conduct. As a result, the cornerstone of pesantren education is the promotion of Islamic virtues, one of which is tolerance.(Atmojo. Arief Eko Priyo, 2015)

This study assumed that Islamic boarding school education has succeeded in producing social cadres who uphold the religious moderation character, and that pesantren alumni who have returned to society are indirectly the custodians of society to counteract the panetration of religious extremism influenced by the current political environment.

In this study, the researcher applied a phenomenological qualitative methodology to make in-depth observations at five renowned Islamic boarding schools in Central and East Java, known as pesantren. (1) Rembang's Pesantren Raudlatut Thalibin, (2) Pati's Pesantren Al Hikmah, (3) Jepara's Pesantren Al Mustaqim, (4) Demak's Pesantren Futuhiyah, and (5) Jombang's Pesantren Al Aqabah In-depth observations of pesantren daily activities and the social environment, as well as documentation and in-depth interviews with five key informants from each of the pesantren studied: kyai, senior teachers, junior teachers, pesantren management students, and non-management students. 
The purpose of this study is to better understand and describe the role of pesantren elements (kyai, santri, mosque, and yellow book) in the process of transmitting the religious moderation character developed and transmitted from kyai to students during their pesantren education, and then from santri to the public after the students complete their pesantren studies.

In-depth observation, documentation, and in-depth interviews were being used to collect data, which was then categorized and classified according to the kind of category, relevant data was selected according to the category to draw conclusions, and it was reverified as part of the validation process. The data analysis approach used in this study was the Miles and Huberman model, which states that "we describe analysis as consisting of three continuous flows of activity: data reduction, data presentation, and conclusion drawing/verification."(Hamid \& Sudira, 2013)

\section{UNDERSTANDING ISLAMIC MODERATION IN PESANTREN NU}

Moderation comes from Latin, which is moderatio which means mediumness. It can also mean self-control (from a very excessive attitude or lack). There are two definitions of moderation in the Indonesian Dictionary, namely reducing violence and avoiding extremism. In English the word moderation comes from the word moderation which has the meaning of average (average), core (core), standard (standard) or nonaligned (impartial). Moderation in general can mean promoting balance in terms of beliefs, morals, and character in treating others both as individuals or in dealing with state institutions (Tim Penyusun Kemenag RI, 2019).

In Arabic, the term al-Wasathiyah refers to Islamic moderation. Tawazun, I'itidal, Ta'adul, and Istiqomah all are terms used by Al-Qardawi that have similar meanings. As a concept, Islamic moderation is a perspective or attitude that demonstrates a constant attempt to put oneself amid an extreme opposing or excessive attitude, with the goal of preventing extreme viewpoints from dominating one's thoughts and attitudes. (Tim Penyusun Kemenag RI, 2019).

The pesantren value system is viewed as a balance that seeks to find a medium ground (wasathiyah) by avoid extremes. Balance is part of a tolerance (tasamuh) attitude of togetherness (ijtima'iyyah), deliberation (shura), and fairness (is) in the midst of a heterogeneous community. As a result, Islamic moderation is a response to the existence of two religious poles: ultra-conservative or extreme right on one hand, and liberal or extreme left on the other (Dakir \& Anwar, 2020)

These attitudes and views are analyzed in this research process, such as how these views can be seen in pesantren daily practices, kyai practices during the learning process with their students, and how these Islamic moderation patterns are transferred in the daily lives of students, all of which have had a positive impact on the formation of santri characters.

Although the ASWAJA curriculum (ahlussunnah wal jama'ah) has become a compulsory subject in school, the insemination of Islamic moderation views is always emphasized in many educational institutions and Islamic boarding schools of Nahdhatul Ulama through various approaches, although in the formal educational process, the ASWAJA curriculum (ahlussunnah wal jama'ah) has become a compulsory subject in school, what is 
more important is how the attitudes are shown. This is the research's main emphasis.

According to numerous sources, Ahlu Sunnah wal-Jama'ah is classified as the Prophet Muhammad PBUH's largest group, that comprises Imam Abul Hasan al-Ash'ari and Abu Mansur al-followers. Maturidi's Sheikh Murtadha az-Zabidi expressed it thus way in Ihya' 'Ulumuddin:

$$
\text { اذاطلق اهل السنة و الجماعة فالمر اد بهم الاشاعرة والماتوردية }
$$

"'The word Ahlus Sunnah Wal Jamaah signified followers of Imams Abul Hasan al-Asy'ari and Abu Mansur al-Maturidi when it was spoken." Sheikh Ibn 'Abidin al-Hanafi says in Hasyiyah Ibn 'Abidin's work, "Ittihafus Sadah al-Muttaqin Worship of Ihya "Ulumiddin."

$$
\text { اهل السنة و الجماعة هم الاشاعرة و الماتوردية }
$$

"Ahlus Sunnah Wal Jamaah is a Muslim who follows Imam Abul Hasan al-'Asy'ari and Abu Mansur al-Maturidi." (Hasyiyah Ibn 'Abidin)

Some of the qualifications for Ahlu Sunnah wal Jama'ah include always being the majority group, sticking to the teachings of the Prophet PBUH and his companions, and not judging Muslims for sin easily. Only followers of Imam Abul Hasan al-'Asy'ari and Abu Mansur al-Maturidi, who are predominantly Muslim converts, make up the aforementioned group of Muslims (Tim Harakah Islamiyah, 2018)

The main features of Ahlussunnah wal Jamaah

The arguments in Islam generally call for an i'itidl (middle stance, moderation) attitude and prohibit exaggeration, which is defined as ghuluw (extreme), fanatical, intelligent, and tashdd (complicates). The term 'adl, which means "middle," is also mentioned in other terms in the Qur'an, such as al-wast and al-qist, which all signify "middle" or "having a middle stance." Similarly, the phrase al-wazn or al-mzn, which signifies balance or a balanced attitude, is used. (Nurdin \& Naqqiyah, 2019)

There are three main features of the teachings of Ahlussunnah wal Jamaah as follows:

(Tim Harakah Islamiyah, 2018)

i. At-tawassuth means moderate, mid-attitude, not extreme left, or extreme right. This is taken from the word of Allah SWT: And so, we make you (the Muslims) the middlemen (just and choice) so that you may be a witness (measure of judgment) on the (attitude and actions) of mankind in general and that Allah SWT may be a witness (measure of judgment) for all your deeds. "(QS al-Baqarah: 143).

ii. At-tawazun means balance in all things, including the use of the 'aqli (rational) and naqli (Quran and Hadith) arguments. This is based on the word of Allah Almighty: "We have sent our apostles with the proof of the truth, and we have brought with them the scriptures and the balance of justice so that men may exercise justice" (QS al Hadid: 25).

iii. Al-i'tidal means straight and upright. As Allah Almighty says in the Qur'an: "O ye who believe, be ye men of justice, for Allah is a just witness. And do not hate your people for making you unjust. Doing good because justice is closer to the righteous. And fear Allah, for verily Allah is Seeing what you do. "(QS al-Maidah: 7)

Apart from these three characteristics, the Ahlussunnah wal Jamaah community also promotes tasamuh, or tolerance, which entails accepting and tolerating diversity, even among those who hold opposing views. This attitude does not imply that these opinions are 
accepted or justified. Allah's SWT Word, which signifies:

"So, speak both of you (Prophet Musa AS and Prophet Aaron AS) to him (Pharaoh) in meek words and hopefully he will remember and be afraid." (Surah Thaha: 44)

\section{Pillars of Islamic Moderation}

Three key aspects underpin Islamic moderation. The first pillar is moderate religious thought, which is characterized by the ability to combine text and context. The art is not solely based on religious texts and forces new relativity and contexts to submit to otoritative text, but rather builds a dynamic dialogue in which the thought generates not only textual but also contextual content.(Tim Penyusun Kemenag RI, 2019).

The second pillar of moderation is movement, particularly in relation to the dissemination of religious values that promote goodness and peace. This movement is centered on the idea of making improvements in a good attitude. (Tim Penyusun Kemenag RI, 2019).

By reinforcing the connections between religious tradition and culture in the local community, the third pillar advocates moderation in religious customs and behaviors. Religion and culture should not be pushed against one other, but rather should engage in mutual dialogue and develop new civilizations. (Tim Penyusun Kemenag RI, 2019).

\section{Preaching and Violence}

The method to religious preaching, or dakwah, is welcoming rather than coercive. The role of God's messengers is to transmit meaning clearly. The task of the messengers of God is to communicate clearly. The Quran says, "There is no need for us except to make it clear." (QS. Yasin: 17)

\section{POLITICS IN THE PERSPECTIVE OF ASWAJA}

According to Aswaja, the most important principle in politics is maslahah, which $\mathrm{Al}$ Gahazali defined as the consideration that provides benefit or prevents damage in accordance with the sharia's goals. Which goals include safeguarding the five fundamental values of religion, life, intellect, lineage, and property (Elvan Syaputra, 2014). Maslahah is achieved by a variety of methods, including agreements and commitment. In the book alMilal wan Nihal, Imam Muhammad bin Abdul Karim As-Syihristani (w. 548 H.), Aswaja highlights an interesting remark that illustrates his political ideas. "Imamah (political leadership) is a concept of maslahah (prevent harm) which is derived from common people choice and leader is appointed based on popular choice by the majority people." (Tim Harakah Islamiyah, 2018).

This notion underpins Ahlu Sunnah Wal Jama'ah's acceptance of any style of political leadership if it complies to syari'ah. If there is a political practice that is not in conformity with the syari'ah, it must be changed by highlighting an effective implementation method.

In terms of Indonesia's national ideology, Aswaja believes that it is necessary to maintain national unity based on the agreed national ideology and obedience to legitimate government and all related policies as long as they do not conflict with religious teachings, not to revolt or try a coup against lawful government; if there are any flaws in the administration, gently remind him.(Tim Harakah Islamiyah, 2018). 
Because the principle of ahlusunnah wal jama'ah emphasizes maslahah in politics, it is not permissible to commit treason when a legitimate government stray from the truth, and it is the Muslim's obligation to give the best advise and to be patient with the ruler's injustice. (Tim Harakah Islamiyah, 2018).

"O you who believe, obey Allah, and obey the Messenger of Allah and keepyour precepts." (QS. An-Nisa: 59).

Imam an-Nawawi (d. 676 H.) quotes al-Qadhi 'Iyadh's (d. 544 H.) opinion that it is compulsory to obey the law of governance according to this verse (ulil amri). The most acceptable meaning of the ulil amri in the cited passage, according to At-Thabari (v. $450 \mathrm{H}$.), is the government (al-umara 'wa ahlus sulthah wal hukmi).

"When a leader has served the people, he has fulfilled his responsibility to Allah," states al-Mawardi in al-Ahkam as-Sulthaniyyah (haqqullah). Two things are necessary for people: obedience and support to the leaders. Scholars of the Ahlus Sunnah highlight the need of obeying the government in both happy and sad times. As a result, experts of Indonesia's Ahlus Sunnah Wal Jamaah condemn any movement that seeks to overthrow the government, defining such activities as bughot (rebellion) and agreeing that such activities is unlawful.

\section{Tolerance and Diversity}

In the context of Indonesia, the Indonesian population follows a diverse variety of faiths. The presence of these religions is officially recognized by the state. Religions are regulated so that they can coexist and foster harmony within the state, which helps to develop national cohesion. As a result, the Muslim community must maintain good interactions with other religious adherents.

Muslims and non-Muslims have quite distinct theological perspectives. Muslims believe that Islam is the truest religion, but they also think that coexisting with people of other faiths is acceptable and that different faiths should not have to be hostile to one another. Faiths may work together to attain a shared vision, as the Prophet Muhammad PBUH demonstrated when he led the city of Medina, which was at the time was composed of people from various tribes and religions. In practice, Prophet Muhammad PBUH nurtures positive relationships with non-Muslims and Jews. Non-Muslims are also dealt with by the Prophet PBUH in terms of commercial and contract deals. If there was no risk of living together, the kind of partnership was maintained within the boundary of good relationship and mutual-relationship, and when such a crisis arose, Prophet Muhammad PBUH always advocated a peaceful resolution or minimized the impact of conflict. During his lifetime, the Prophet Muhammad SAW s trive to achieve the common good as much as possible whilst also avoiding harm to the earth (Tim Harakah Islamiyah, 2018).

\section{CONSERVATIVE TURN AND THE PHENOMENA OF PUBLIC RELIGIOSITY}

Since the fall of the new order regime, Indonesia has displayed a new color for the different face of Indonesian Islam, the so-called 'the smiling face of Islam' which has been a general picture of the face of Islam in Indonesia, changing along with the spread of horizontal conflicts triggered by inter-religious conflicts in several regions in Indonesia. The existence of Jihadi movement, as culmination of social friction after the dismemberment New Order regime, making religion as an arousing social sentiment to trigger conflicts 
among religious communities. This condition also triggered by the influence of the transnational terrorism network which also has a large interest in this Muslim-majority country.

On the other hand, the decentralization policy has provided ample space for marginalized groups to speak out loudly, alongside assurances of freedom of expression, which the government then revoked several regulations that were considered to restrict press life after the reform, thereby indirectly providing space for freedom of opinion as a motivating factor for the Islamist movement to act. (Bruinessen, Martin. v., 2013).

Of course, the image of the rise of conservatism is understandable, particularly considering how the multiple events were linked and demonstrate trends in the same direction. (Bruinessen, 2013, pp. 1-21), Following many terror attacks during the Christmas celebrations in 2000, the Bali Bomb happened in October 2002, killed nearly 200 people and injuring hundreds more, the majority of whom were international tourists. In the 2000s, a public opinion poll demonstrated growing sympathy for Muslim militant organisations and broad support for the notion of an Islamic state. This was strengthened by public demand for the return of the seven words in the first principles of the Pancasila as stated in the Jakarta charter, which were ultimately rejected at MPR sessions in 2001 and 2002, but just how did this not discourage conservatives from making moves at the regional level, and then how did many emerging provincial sharia regulations established in local level of government (Baidhawi, 2015).

As many intellectual figures who were active in the contestation of thought discourse, shifting their direction in political career and in political institutions, this cause weakens the process of building a solid social basis for the years ahead.

Another important external factor is the influence of Middle Eastern hegemony in the form of the return of Muslim scholars commonly graduated from Saudi or Kauwait sponsored educational institutions or the translation process of fundamentalism texts resources into Indonesian language which also sponsored by transnational Islamic movement. Therefore, within short period or time either NU or Muhammadiyah ultimately realised that many of their congression has been infiltrated by transnational network and at the sametimes numerous Muhammadiyah's educational institution, administratively has been taken by their activists by changing the school curriculum and the name of school. Similarly, numerous mosques which basically as NU and Muhammadiyah cultural basis, gradually has been occupied by conservative groups and drastically changing the atmosphere of da'wa by monopolising religious sermon delivered only by their groups (Bruinessen, Martin. v., 2013).

This legacy only contributes to the popularity of religious symbols in public areas, and these symbols appear to be more of a social trend than a substantive faith at same time. As a result, some of the following issues arise because of this situation.

a. Religious Populism

The syar'i phenomenon, which began as a social trend, has gradually taken over public space and expanded into a social demand that can be found in many aspects of Indonesian culture. This syar'i label consequently becomes a source of joy for a Muslim in expressing his diversity in public spaces, and it indirectly becomes a societal norm for religiousity. Unfortunately, public religiosity is used as a standard for judging one's commitment to one's religion, which is, to some extent, the expression of religiosity leading toward religious 
exclusivity, which leads to fanaticism. Certain data leads to social vulnerability, which is characterized by numerous intolerant acts involving grassroots groups, this situation is certainly not without reason.

For example, according to a study issued by the Setara Institute for Democracy and Peace (Kompas.com, 2018), there was an increase in violations of freedom of religion and belief in the middle of 2018. (KBB). As compared to mid-2017, while there were $80 \mathrm{KBB}$ events with 99 violations, mid-2018 have seen a significant increase in KBB violations, with $109 \mathrm{KBB}$ violations events with 136 violations.

Fanaticism, on the other hand, is characterized by the growth in the spreading of hate speech, hoaxes, defamation, and provocation through social media networks. According to various mainstream news reports, the National Police handled 3,325 hate speech cases in 2017, rising 44.99 percent from 1,829 cases in 2016.

1) Strengthening Politics of Identity

Politics, from an Islamic perspective, may be defined as an activity that manages, regulates, and manages the lives of individuals and nations by leading them down the track of people's welfare. Participation in politics, as according Islam, is an action that can provide virtue, rewards, and interests (Asiyah \& Chasanudin, 2020)

Thus, religious populism has a positive influence on identity politics, as seen by Joko Widodo's election as president in 2014, which was defined by identity politics trends and indirectly dismissed the concept of a primordial political culture in Indonesian society as baseless.

However, how the 2014 presidential election's legacy has hardened societal demarcation boundaries into categorizations based on SARA-based primordial divisions. The significance of identity politics in this transition process exacerbates identity concerns, raising the risk of horizontal conflict, thus endangers social security (Hamidah, 2018).

Religious-based political populism remains significant in Indonesia, given that the religious element is one of the seven levels of the universal cultural element that is the most difficult to transform and has become a very sensitive issue (Koentjaraningrat, 1974).

In the Indonesian context, religious-based political populism remains relevant, bearing in mind that the religious element is one of the cultural elements of the seven levels of the universal cultural element which is the most difficult to change and become very sensitive issue (Koentjaraningrat, 1974). As a result of such a social situation, identity politics has gained considerable momentum as a strategic strategy to promoting public solidarity and popularity.

2) Media Information Technology and Digital Religious Phenomenon

Many scholars have used the phrase "digital religion" since the mid-1990s when cyberspace began to be introduced and entrenched in society. The phrase "digital religion" or "cyber religion" is used to describe the interaction between religion and technology. When religious spiritual practices from many cultures are brought to life in cyberspace, it demonstrates how vital religion is. Of course, this fundamental shift in digital technology's growth has had an influence on religious culture, as individuals have began to discover methods for their faith to be felt in digital culture. As a result, it's not unexpected that the phrase "digital religion" has been used to describe the transition from offline to online religious behaviors (Campbell, 2013).

This religious expression in digital space may be seen in a variety of ways, including 
an increase in the number of Islamic websites, a Youtube channel focused to Islamic studies, Instagram accounts, and even mainstream social media. Unpublished publications on digital contestation on mainstream and non-mainstream Islamic websites continue to demonstrate vulnerability, with digital material regarding Islamic moderation discourse unable to dominate digital public space (Hamidah, 2019).

\section{PESANTREN PRAXIS IN BUILDING ISLAMIC MODERATION}

This study found that pesantrens generally cultivate an Islamic moderation mindset not directly in the form of a measurable curriculum and implemented in the form of classically specific teaching, data that have been collected and interviews with several pesantren leaders (kyai) and observations of daily activities in several pesantrens. Because cultivating this idea is a continuous that is woven into everyday teaching in pesantren culture. However, there is a common thread in the process of forming this mentality, notably the teaching of the yellow classical resource book (kitab kuning), which has become the pesantren's hallmark and indirectly teaches santri how past ulema formed their opinions via extensive argument. As a result, if Santri understands how the pattern of differing opinions from previous scholars, they will be forced to develop an open-minded attitude, particularly when it comes to differing opinions, and this may be a benefit for students once they become involved in their social lives. (2019, Makin). This culture is then transferred towards how pesantren engage with the society daily. This process is used in pesantren to cultivate ASWAJA ideology in a contextualized manner. Pesantren further strengthened the ideologization of the important principles of ASWAJA, namely Tawazun, Tasamuh, and Ta'adul, with the growing sentiment of social religiosity within Indonesian society, which to some level raises the sentiment of group exclusivism (Muhsin, 2019). These three concepts may also be explicitly evaluated in pesantren practice when faced with the dynamic of social difference.

This is notably done by pesantren in protecting students from extremist ideas penetrating the class, especially for sensitive themes taught throughout the learning process in a specialized forum, especially to senior students who are regarded to grasp the current social environment.

Of course, the practice of tawazun is evident in the last presidential election campaign, when the majority of pesantren put themselves in a position to mediate in a politically fragmented society, as expanding identity politics has had an influence on the division of society. According to conversations with pesantren leaders, most pesantren reluctantly participate in the presidential election discourse. Even though Kyai had chosen his preference, Pesantren as an educational institution did not force or direct students to vote for a specific political candidate.

This is obvious from Faqih's statement in the interview with KH. Faqih, who stated that "pesantren must play the politics of nationalism because it is not a political institution." So, every individual in the pesantren has the right to make political choices, institutionally the pesantren must place an attention on serving the nation, for all members of the community, regardless of political preferences, so that, with wisdom, pesantren can become mediators for potential social polarization. And the pesantren could helps with that (Faqih, 2019). 
Pesantren also have a tasamuh mentality in their social interactions with non-Muslim communities. In Pesantren Raudhatut Tholibin Rembang, which is in the midst of nonMuslim populations, this mentality is demonstrated on a daily basis. And this relationship may be observed in how these santri perform congressional death prayers on their nonMuslim neighbors, or how KH Bisri, who leads non-Muslim corpses, illustrates this practice, even though KH Bisri performs congregational prayers Dhuhur with some of his students. Of course, this is done out of respect for the families who have been touched by loss of the family member (Syarofudin, 2019).

The attitude of Islamic moderation is also built through an artistic approach; this praxis is found in Jepara, Rebana art from Al Mustaqim Islamic Boarding School is a hereditary legacy from the previous generation, which aims to encourage people to be interested to learn in pesantren. Until now the Rebana Group is often asked to enliven community celebration events, which indirectly as a form of da'wah bil-ma'ruf (propaganda in a good way) to ordinary people (Sholahudin, 2019)(Karim et al, 2021). How Langgar Angkruk became the forerunner to the pesantren which was only a place where young people spend time. Youths who are interested in tambourines are then provided with a set of tambourine tools to facilitate their hobby, from this process they then get orders to perform at a celebration event in the community, then this tambourine group not only plays tambourines but then they taugh how to recite the Holy Qur'an and study about religion. From this expression, it can be seen how the pattern of pesantren approach in embracing the public through a long and continuous process.

Equally important is the readiness of pesantren in accommodating the development of information technology, although in most pesantren, commonly they have not proportionally prepared their students in contact with the digital world, but in the case of PP. Al Aqobah, PP Futuhiyah Mranggen and PP Roudhatut Thalibin, this digital world becomes important, (Faiz, 2019) the praxis of how pesantren have tried to fulfil the digital public with positive content, and how Pesantren Al Aqobah itself has declared as digital pesantren as the learning process has been done paperless. This is done with the consideration that students will inevitably face the digital world, so it is necessary to prepare how to take blessing of this digital technology to spread positive messages, then on the other hand also to prepare students so that they do not become digital literate figures (Faqih, 2019).

Another case with PP Roudhotut Thalibin, where Gus Mus's character became a magnet for citizens and one of the respected figures in the digital world. Gus Mus Channel be it on Youtube, IG, Twitter, FB always broadcast status or peaceful messages. This is of course not without reason, the upheaval of the presidential election contestation has made people blaspheming with each other, hoak and utterance of hatred filled the digital timeline and how does Gus Mus assert 'not the right time to lose' not by means of counterless narration and endless debate, however, by spreading peace messages that can be accessed by the digital public. This process makes students also motivated to do the same thing, namely by filling the timeline with positive messages.

This view of Islamic moderation is also seen in the da'wah approach, known by the term amar ma'ruf nahi munkar, where almost all the kyai strongly disagree with the da'wah approach through violent means, blaming different people by stigmatizing infidels or heresy, sweeping in a violent way. The general view of pesantren, da'wah must always be 
done within the scope of amar bil ma'ruf or inviting goodness by means of kindness, not by means of violence. Of course, this is not limited to a slogan, because in practice how the Futuhiyah boarding school in the eradication of drug trafficking, does not necessarily conduct vigilante alone, but by asking the authorities to help resolve (Faiz, 2019).

Thus, in general how the discourse of Islamic moderation has entrenched in NU pesantren beyond the formal education curriculum.

\section{ISLAMIC BOARDING SCHOOLS BUILD ISLAMIC MODERATION ATTITUDES}

The existence of pesantren certainly cannot be separated from the existence of 'kyai'. The word 'kyai' according to the ancient Javanese language means a respected person. The words 'kyai' itself is a statement of Javanese calls to his grandfather, so, kyai can be interpreted as parents, even more than that 'kyai' not only means old, but also sacred (Madjid, 1997). In practice, the kyai-santri relation is heavily influenced by the concepts of stratification of the Javanese people themselves, so that santri always look at kyai in the recitation as people who absolutely must be respected and obeyed by his words. Because respecting and obeying kyai will bring blessings to the students so that their knowledge will be useful in the future. In the monumental book 'Ta'limul Muta'allim written by Shaykh Zarnuji is one of the books taught in almost all NU pesantren and exerts a deep influence on the pattern of relations in the kiai-santri relationship. From here, the figure of the kyai is a non-formal leader as well as a spiritual leader who is close in the community, so that kyai in the tradition of the NU pesantren community are culturally constructed, so that the kyai, besides being a teacher for his students, is also a community figure respected by the surrounding community.

This pattern is still obtained by researchers from the pesantren visited, in the case of PP Roudhatut Thalibin Rembang, PP Permata, Kajen Pati, PP Al-Aqabah Jombang and Al Mustaqim Jepara, all are pesantren which was continued by the second generation of the early founders of the pesantren, while PP Al Futuhiyah Mranggen Demak, has entered the fourth generation and how the messages and practices of Islamic moderation from the predecessors of the pesantren are still passed down for generations to pesantren students (santri), from which the internalization of the Islamic moderation view is internalized to santri and indirectly builds such a mindset on santri.

The story of how Kiai Bisri became the imam of a non-Muslim corpse prayer became a story that was passed down for generations, as well as how relations with non-Muslim communities were also exemplified in his practice of interacting with non-Muslim neighbors who live in a pesantren neighborhood (Makin, 2019). Likewise, how was it in the early days of the establishment of the Al Mustaqim pesantren which was a 'Langgar Angkruk', when Kiai Muhsin tried to invite the young men around to play tambourines by providing set of tambourine tools. Of course, this story becomes an explicit Islamic moderation education for students and gives a message in the dynamics of the da'wah approach in the community and the amar ma'ruf nahi munkar approach that emphasizes wisdom and goodness and not by violence (Sholahudin, 2019).

The views of tasamuh, tawwazun and ta'adul, both verbally delivered by the kyai through the study session or through the pesantren praxis in its relations in society, has a lot of influence on building Islamic moderation views on students (santri). This is where the 
process of internalizing the Islamic view of moderation is built up, both directly and indirectly and absorbed by students as a form of respect for students to kyai with the hope that what students learn during the pesantren will bring a lot of blessings to later life in society.

Practically, the view of Islamic moderation has assumed influenced the mindset of santri, especially this is seen in during the process of interview, which is conducted separately. Where during the process of in-depth interview, the same questions was raised by researchers to kyai of the pesantren, and to the santri, which interestingly when comparing the substance of the answers of the kyai and santri caregivers, will get an agreement that is not much different from the answers given by the santri and kyai, so the conclusions of this in-depth interview gave an explicit message that this view of Islamic moderation had shaped the santri mindset.

On the other hand, senior santri often get assignments to become an extension of the pesantren in the community, for example when one of the non-Muslim neighbors who live opposite the Roudhotut Tholibin pesantren is having a celebration in the form of a sermon, without hesitation they are inviting these santri to enliven, even to invite santri to read manaqib (Makin, 2019). Likewise, one of the students of PP Al-Mustaqim's daughter, where the santri after completing the pesantren, was often asked to become religious speakers for sessions of women villagers, lead manaqibs and listen to the reading of the Qur'an at the parents' assembly. Likewise, when they were asked in their daily practices, they found differences in their views, both amaliah and the views of the santri, stating that they did not question the differences and did not force their views on different people (Sholahudin, 2019).

Amid the rapid development of information technology, pesantren also play important role in contributing moderate Islamic digital content, mostly these activities done by pesantren students. These students contribute to build digital content such as the Gus Mus Channel, similar effort also done by Pesantren Al Aqobah. In one of the quotes published on Instagram account of PP Al Aqobah stated: "Goodness (ma'ruf) is logical and easy to understand, therefore it should be done and something that is no goodness (ma'ruf) is not logical and could not be understood, if it is done so it must be abandoned'. It is in this way how the messeges of Islamic moderation spread by student (santri) in digital public so that it can be accessed by digital public.

\section{CONCLUSION}

Taking into account the description of how the process of building Islamic moderation views in pesantren, as above, it can be concluded that the santri-kyai relation has an impact in santri's character building, and thus from this learning process, transfer of knowledge between santri-kyai has contributed in strengthening Islamic moderation view on students, therefore in the next step has an impact on how students' behavior in social relations once these student has been completed their pesantren learning.

From the above explanation, it can be concluded that: first, the kyai-santri relationship has an impact on the formation of santri characters in pesantren, such that the learning process of the kyai, as well as the educational process during the period of learning in pesantren, has contributed to strengthening the view of Islamic moderation on santri, and therefore, in the next stage, it has profound effects on character building of students, particularly related to their social relations once they completed their pesantren leaning. 
Second, the kyai's role is not only that of a pesantren leader, but also of a true community figure and an influential role model in society. The recent political contestation in Indonesia explains how the majority of kyai play a critical role as a mediator between the opposites. Third, the practice of amar ma'ruf nahi munkar with a goodness-based approach (makruf) becomes a general pattern that the kyai teach both explicitly and implicitly to his students. This practice indirectly protects students from vigilant behavior as well as the explicit character of moderation in confronting extremist viewpoints, making it an important barrier against Islamic extremism. This viewpoint also contributes to a tolerance attitude, which is illustrated in the PP Raoudhotut Tholibin case, which demonstrates how tolerance is integrated into the structure of social interaction between religious communities. To conclude this study, the client-patron pattern, that is built in the form of the kyai-santri relationship and strengthened by genealogy lines, contributes to the internalization of Islamic moderation views for santri. In this way, not only is mediation attitude built into discourse, but genealogical authority factors also strengthen the internalization process of Islamic moderation to santri.

\section{REFERENCE}

Asiyah, S., \& Chasanudin, A. (2020). Pondok Pesantren dan Dakwah Politik: Kajian Histori Pondok Pesantren Hasyim Asy'ari Bangsri Jepara. Jurnal Ilmu Dakwah, 40(1).

Atmojo. Arief Eko Priyo. (2015). Pesantren dalam Budaya Pendidikan. IBDA: Jurnal Kebudayaan Islam, 2, 173-175.

Baidhawi, Z. (2015). Fikih Kebinekaan Pandangan Islam Indonesia Tentang Umat, Kewargaan dan Kepemimpinan Non-Muslim. Mizan Media Utama.

Bruinessen, Martin. v. (2013). Contemporary Developments in Indonesian Islam Explaining the "Conservative Turn." ISEAS Publishing, Institute of Southeast Asian Studies.

Campbell, H. A. (Ed.). (2013). Digital Religion, Understanding Religious Practice in New Media Worlds. Routledge.

Dakir, D., \& Anwar, H. (2020). NILAI-NILAI PENDIDIKAN PESANTREN SEBAGAI CORE VALUE; DALAM MENJAGA MODERASI ISLAM DI INDONESIA. Jurnal Islam Nusantara, 3(2), 495-517.

Elvan Syaputra. (2014). Maslahah as an Islamic Source and its Application in Financial Transaction. Quest Journals Journal of Research in Humanities and Social Science, 2, 6671.

Hamid, A., \& Sudira, P. (2013). Penanaman nilai-nilai karakter siswa smk salafiyah prodi tkj kajen margoyoso pati jawa tengah. Jurnal Pendidikan Vokasi, 3(2).

Hamidah, K. (2018). The Trend of Emerging Identity Politics in Indonesia and the Challenge in Fostering Social Cohesion: Lesson Learned from Jakarta Provincial Election. Karsa: Journal of Social and Islamic Culture, 26, 91-109.

Hamidah, K. (2019). The Discourse Phenomenology of Digital Dakwah and the Challenge of Islamic Modereate Mainstream Media in Seizing Digital Public. AICIS.

Karim, A., Adeni, A., Fitri, F., Fitri, A., Hilmi, M., Fabriar, S., \& Rachmawati, F. (2021). Pemetaan untuk strategi dakwah di kota semarang menggunakan pendekatan data mining. Jurnal Dakwah Risalah, 32(1). doi:http://dx.doi.org/10.24014/jdr.v32i1.12549.

Karim, A., Suharno, Y., \& Arwani, W. (2019). Pemberdayaan Sekolah Islam untuk Meningkatkan Kompetensi Profesionalisme Guru di Kabupaten Semarang. Jurnal Ilmu Dakwah, 39(1), 91-100. DOI : 10.21580/jid.v39.1.4421. 
Koentjaraningrat. (1974). Kebudayaan dan Mentalitas Pembangunan. Gramedia Pustaka Utama.

Madjid, N. (1997). Bilik-Bilik Pesantren. Paramadina Press.

Ministry of Religious Affairs. (2019). Pesantren Data Centre.

Nurdin, A., \& Naqqiyah, M. S. (2019). Model Moderasi Beragama Berbasis Pesantren Salaf. Islamica: Jurnal Studi Keislaman, 14(1), 82-102.

Shiddiq, A. (2005). Khittah Nahdliyyah (3rd ed.). Khalista dan LTN NU.

Tim Harakah Islamiyah. (2018). Buku Pintar ASWAJA. Harakah Islamiyah.

Tim Penyusun Kemenag RI. (2019). Moderasi Beragama. Badan Litbang dan Diklat Kementrian Agama RI. 